\title{
PELATIHAN PENELITIAN TINDAKAN KELAS BAGI GURU IPA KABUPATEN MANOKWARI PAPUA BARAT
}

\author{
Sri Wahyu Widyaningsih ${ }^{1}$, Irfan Yusuf ${ }^{*}$, Insar Damopolii ${ }^{3}$ \\ $1,2^{*}$ Jurusan Pendidikan Fisika, Universitas Papua, Indonesia \\ ${ }^{3}$ Jurusan Pendidikan Biologi, Universitas Papua, Indonesia \\ $\underline{\text { s.widyaningsih@unipa.ac.id }}^{1}$, i.yusuf@unipa.ac.id ${ }^{2}$, $\underline{\text { i.damopoli@unipa.ac.id }}^{3}$
}

\begin{abstract}
ABSTRAK
Abstrak: Penelitian Tindakan Kelas (PTK) merupakan kegiatan penelitian tindakan yang dilakukan oleh guru di kelas. Artikel ini merupakan hasil kegiatan Pengabdian Kepada Masyarakat (PKM) yang dilakukan oleh tim PKM Fakultas Keguruan dan Ilmu Pendidikan Universitas Papua. PKM ini bertujuan untuk melatih kemampuan menyusun PTK bagi guru IPA yang ada di Kabupaten Manokwari Papua Barat. Pelatihan diberikan kepada guru-guru IPA yang ada di Kabupaten Manokwari yang dihadiri oleh 35 orang guru IPA dari 17 sekolah SMP yang ada. Metode yang digunakan dalam pelaksanaan pelatihan ini yaitu metode ceramah, diskusi, demonnstrasi dan latihan penyusunan perangkat dan pelaksanaan PTK. Instrumen yang digunakan yaitu angket respon yang diisi oleh peserta pelatihan untuk mengetahui tanggapan mereka tentang PTK dan pelaksanaan kegiatan pelatihan PTK. Teknik analisis data menggunakan pemodelan Rasch. Hasil analisis diperoleh nilai person measure $+0,11$ lebih besar dari 0,00 logit yang menunjukkan bahwa peserta pelatihan setuju terhadap pelaksanaan kegiatan pelatihan PTK. Berdasarkan hasil penelusuran pernyataan angket, sebagian besar guru belum pernah melaksanakan PTK sebelumnya sehingga pemahaman mereka tentang PTK masih perlu untuk terus dikembangkan. Kegiatan pelatihan PTK sangat membantu guru-guru IPA di Kabupaten Manokwari dalam menyusun perangkat, melaksanakan, mengevaluasi, dan melaporkan hasil PTK.
\end{abstract}

Kata Kunci: Pelatihan; Penelitian Tindakan Kelas; Respon.

Abstract: Classroom Action Research (CAR) is an action research activity carried out by the teacher in the class. This article was the result of Community Service activities conducted by a team of lecturers from the Teacher Training and Education Faculty, Universitas Papua. This activity aims to train the ability to develop CAR for science teachers in Manokwari District, West Papua. The training was given to the existing science teachers in Manokwari District, which was attended by 35 natural science teachers from 17 existing junior high schools. The method used in the implementation of this training was the method of lecture, discussion, demonstration and training in the preparation of tools and implementation of CAR. The instruments used were response questionnaires filled out by training participants to find out their responses about CAR and the implementation of CAR training activities. The data analysis technique uses Rasch modeling. The results of the analysis obtained a person measure value of +0.11 greater than 0.00 logit which indicates that the training participants agreed to the implementation of CAR training activities. Based on the search results of the questionnaire statement, most teachers have never implemented CAR before so their understanding of CAR still needs to be developed. CAR training activities are very helpful for science teachers in Manokwari Regency in compiling devices, implementing, evaluating, and reporting on $C A R$ results.

Keywords: Training; Classroom Action Research; Response. 


\section{A. LATAR BELAKANG}

Salah satu bentuk penelitian yang menggunakan refleksi diri dan dilakukan oleh orang yang terlibat langsung di dalamnya untuk melakukan perbaikan berbagai aspek adalah penelitian tindakan (Kemmis, McTaggart, \& Nixon, 2013). Dalam rangka pengembangan profesionalisme, guru tidak bisa melepaskan dirinya dari kegiatan akademik penelitian. Dalam kegiatan akademik penelitian, guru memiliki peran strategis dalam pengembangan kompetensi profesional sekaligus sebagai upaya dalam meningkatkan dan memperbaiki proses maupun hasil belajar peserta didik. Penelitian yang berfokus pada perbaikan kualitas pembelajaran yaitu Penelitian Tindakan Kelas (PTK). PTK pertama kali diperkenalkan oleh Kurt Lewin pada tahun 1946. Gagasan utama Lewin inilah yang selanjutnya dikembangkan oleh berbagai ahli antara lain Kemmis, McTaggart, Elliot, dan Ebbutt.

Tujuan utama PTK adalah untuk mengubah perilaku pengajaran guru, perilaku peserta didik di kelas, dan/atau mengubah kerangka kerja melaksanakan pembelajaran kelas (Yamtinah, Saputro, \& Masykuri, 2011). PTK merupakan suatu penelitian tindakan yang berusaha menyelesaikan masalah-masalah aktual yang dihadapi oleh guru dalam kegiatan pembelajaran (Wiganda, 2017). PTK dilakukan untuk mendorong kemampuan refleksi secara kritis daripada secara reflektif (Kinsler, 2010). PTK cukup efektif karena dapat dilakukan oleh guru tanpa harus meninggalkan tugas mengajarnya (Asmarani, 2014). Guru mempunyai peran ganda dalam pelaksanaan PTK yaitu sebagai praktisi dan peneliti. Guru dapat secara langsung mengajar dan meneliti untuk menyelesaikan berbagai permasalahan dan kesulitan belajar yang dialami oleh peserta didik selama kegiatan pembelajaran (Siregar, 2014). Pelaksanaan PTK oleh guru sangat penting dilakukan untuk mengatasi berbagai permasalahan belajar yang dihadapi oleh peserta didik.

Berdasarkan hasil observasi selama mahasiswa Fakultas Keguruan dan Ilmu Pendidikan Universitas Papua (FKIP UNIPA) melakukan Program Latihan Profesi (PLP) di berbagai sekolah SMP di Kabupaten Manokwari Papua Barat, diperoleh bahwa pemahaman guru-guru dalam melakukan PTK masih kurang. Sebagian besar guru-guru IPA SMP di Kabupaten Manokwari tidak pernah melakukan PTK. Selain itu, berdasarkan hasil observasi dan wawancara pada beberapa guru SMP yang ada di Kabupaten Manokwari, bahwa para guru masih kesulitan dalam melaksanakan PTK. Para guru masih mempunyai keterbatasan kemampuan dan pengalaman meneliti. Untuk itu, salah satu cara untuk meningkatkan profesionalisme guru adalah guru harus dilatih dan diberdayakan melalui berbagai program inovatif (Amdriyani, Farida, \& Wibowo, 2018). Kegiatan meneliti maupun menulis terutama pelaksanaan PTK, menjadi kegiatan yang harus dapat dilakukan oleh guru. Dalam menyusun proposal PTK guru masih kesulitan dalam menyusun latar belakang, kerangka teoritis, dan metode 
berupa tahapan pembelajaran yang akan dilakukan selama pelaksanaan kegiatan PTK. PTK sebagai metode untuk memberdayakan guu sebagai praktisi pendidikan untuk belajar meneliti (Ericson-Lidman \& Strandberg, 2013). Hasil PTK bermanfaat bagi guru yaitu dalam hal pengajuan kepangkatan. Guru-guru yang akan mengajukan kenaikan pangkat, diharapkan telah melakukan kegiatan PTK dan melaporkan kegiatan PTK baik dalam bentuk laporan yang diseminarkan maupun tulisan di artikel jurnal.

Hasil studi awal kondisi guru-guru IPA yang ada di Kabupaten Manokwari Papua Barat yaitu sebagian besar guru IPA yang ada, belum memiliki golongan kepangkatan dan/atau honorer. Kondisi kepangkatan dari 35 guru IPA di 17 SMP yang ada di Kabupaten Manokwari dapat dilihat pada Gambar 1. Hasil wawancara dengan beberapa guru di Kabupaten Manokwari, menunjukkan bahwa menyusun PTK bagi mereka merupakan salah satu bentuk keterpaksaan bukan sebagai bentuk pengembangan profesi. Hal ini yang menjadi kendala mereka dalam pengajuan kenaikan pangkat.



Gambar 1. Sebaran Kepangkatan Guru IPA di Wilayah Manokwari Barat dan Timur

Hasil wawancara dengan mahasiswa yang mengadakan PTK di beberapa sekolah SMP yang ada di Kabupaten Manokwari bahwa guru tidak mau menjadi guru model dalam penelitian. Alasan guru bahwa mereka tidak menguasai langkah-langkah penelitian PTK, kurangnnya pemahaman terhadap model pembelajaran yang akan digunakan, ketidaktahuan guru terhadap taksonomi Bloom sehingga pembuatan tes hasil belajar mengacu pada soal-soal yang ada di lampiran belakang materi pada buku teks pelajaran. Selain itu terdapat beberapa guru yang tidak mempunyai latar belakang sebagai sarjana pendidikan melainkan sarjana ilmu sains. Dengan latar pendidikan non guru menyebabkan banyak guru yang tidak menguasai PTK. Berdasarkan masalah yang ada, maka sangat 
penting dilakukan kegiatan pelatihan PTK bagi guru-guru IPA di Kabupaten Manokwari Papua Barat. Diharapkan dengan dilakukannya kegiatan PKM berupa pelatihan dan pendampingan dalam melakukan PTK, maka guru-guru dapat memahami dengan baik pelaksanaan PTK serta termotivasi dalam melakukan PTK dengan menerapkan berbagai pembelajaran inovatif di kelas mereka.

\section{B. METODE PELAKSANAAN}

Pelaksanaan pelatihan PTK dilakukan oleh tim PKM FKIP UNIPA melalui kerjasama Dinas Pendidikan dan Kebudayaan Kabupaten Manokwari Papua Barat. Metode yang digunakan dalam pelaksanaan kegiatan pelatihan penyusunan PTK bagi guru IPA di Kabupaten Manokwari Papua Barat yaitu metode edukasi, latihan, dan pendampingan penyusunan perangkat dan pelaksanaan PTK. Kegiatan pelatihan PTK dilaksanakan di Kampus UNIPA dan selanjutnya dilakukan penerapan PTK di beberapa sekolah di Kabupaten Manokwari. Tahapan yang ditempuh dalam pelaksanaan kegiatan pelatihan PTK sebagaimana ditunjukkan pada Tabel 1.

Tabel 1. Tahapan Pelaksanaan Pelatihan PTK

\begin{tabular}{|c|c|c|}
\hline No. & Kegiatan & Tahapan \\
\hline 1 & $\begin{array}{l}\text { Studi awal sebelum } \\
\text { pelaksanaan } \\
\text { pelatihan PTK }\end{array}$ & $\begin{array}{l}\text { - Koordinasi dengan Dinas Pendidikan dan } \\
\text { Kebudayaan Kabupaten Manokwari terkait } \\
\text { peserta pelatihan dan waktu kegiatan } \\
\text { - Pembuatan dan distribusi persuratan untuk } \\
\text { pelaksanaan pelatihan PTK ke SMP yang ada di } \\
\text { Kabupaten Manokwari yaitu berjumlah } 17 \text { sekolah } \\
\text { yang tersebar di Manokwari Barat dan Manokwari } \\
\text { Timur } \\
\text { - Membuat materi pelatihan } \\
\text { - Menyiapkan bahan-bahan pelatihan }\end{array}$ \\
\hline 2 & materi & $\begin{array}{l}\text { - Memaparkan materi tentang PTK } \\
\text { - Metode pelatihan yang digunakan yaitu ceramah, } \\
\text { demonstrasi, diskusi, dan small group discussion. }\end{array}$ \\
\hline 3 & $\begin{array}{l}\text { Latihan } \\
\text { penyusunan } \\
\text { perangkat dan } \\
\text { pelaksanaan PTK }\end{array}$ & $\begin{array}{l}\text { - } \text { Mempersiapkan bahan-bahan untuk penyusunan } \\
\text { perangkat PTK } \\
\text { - Membuat perangkat untuk pelaksanaan PTK } \\
\text { - Penentuan sekolah lokasi pelaksanaan PTK } \\
\text { - Metode yang digunakan dalam kegiatan ini yaitu: } \\
\text { observasi, wawancara secara langsung, dan } \\
\text { evaluasi berupa pemberian angket tentang } \\
\text { pelatihan PTK }\end{array}$ \\
\hline
\end{tabular}

Pemahaman peserta pelatihan terhadap PTK diketahui berdasarkan observasi, pendampingan, wawancara secara langsung, dan pemberian instrument non test. Instrumen non test yang digunakan untuk mengukur tingkat pemahaman peserta terhadap PTK yaitu berupa angket respon yang diisi oleh peserta pelatihan untuk mengetahui tanggapan mereka 
tentang PTK dan pelaksanaan kegiatan pelatihan PTK. Penyusunan angket penilaian peserta dibuat dengan menempatkan beberapa pernyataan negatif sehingga peserta diharapkan teliti dalam memiliki pilihan yang disediakan. Kegunaan pernyataan negatif pada angket sangat penting untuk mengetahui jika mereka sembarangan dalam memilih. Adapun pernyataan angket respon yang diberikan kepada peserta pelatihan sebagaimana pada Tabel 2.

Tabel 2. Indikator dan Pernyataan Responden terhadap Pelaksanaan Pelatihan PTK

\begin{tabular}{|c|c|c|c|}
\hline No. & Indikator & $\begin{array}{l}\text { Nomor } \\
\text { Butir }\end{array}$ & Pernyataan \\
\hline \multirow[t]{6}{*}{1} & \multirow{6}{*}{$\begin{array}{l}\text { Penguasan } \\
\text { Teoretis }\end{array}$} & $+\mathrm{P} 1$ & a. Memahami landasan pelaksanaan PTK \\
\hline & & $+\mathrm{P} 3$ & $\begin{array}{l}\text { b. Mengetahui perbedaan PTK dengan penelitian } \\
\text { lainnya }\end{array}$ \\
\hline & & $+\mathrm{P} 5$ & c. Memahami model-model pelaksanaan PTK \\
\hline & & $+\mathrm{P} 7$ & $\begin{array}{l}\text { d. Mengetahui berbagai model pembelajaran } \\
\text { inovatif dalam melaksanakan PTK }\end{array}$ \\
\hline & & $+\mathrm{P9}$ & e. Memahami cara menganalisis hasil PTK \\
\hline & & $-\mathrm{P} 11$ & f. Kesulitan dalam pelaporan PTK \\
\hline \multirow[t]{3}{*}{2} & \multirow[t]{3}{*}{$\begin{array}{l}\text { Penguasan } \\
\text { Kognitif }\end{array}$} & $+\mathrm{P} 13$ & $\begin{array}{l}\text { a. Mampu mengidentifikasi permasalahan } \\
\text { pembelajaran dalam rangka melakukan PTK }\end{array}$ \\
\hline & & $+\mathrm{P} 15$ & $\begin{array}{l}\text { b. Adanya perbaikan secara bertahap dan terus } \\
\text { menerus selama melaksanakan PTK }\end{array}$ \\
\hline & & $+\mathrm{P} 17$ & $\begin{array}{l}\text { c. Mampu mengidentifikasi karakteristik peserta } \\
\text { didik }\end{array}$ \\
\hline \multirow[t]{6}{*}{3} & \multirow{6}{*}{$\begin{array}{l}\text { Kemampuan } \\
\text { Teknis }\end{array}$} & $+\mathrm{P} 20$ & a. Memahami cara membuat instrumen PTK \\
\hline & & $+\mathrm{P} 19$ & b. Memahami cara pelaksanaan PTK \\
\hline & & $+\mathrm{P} 18$ & $\begin{array}{l}\text { c. Memahami cara melakukan pengamatan saat } \\
\text { PTK }\end{array}$ \\
\hline & & $+\mathrm{P} 16$ & $\begin{array}{l}\text { d. Memahami cara melakukan refleksi } \\
\text { pelaksanaan PTK }\end{array}$ \\
\hline & & $+\mathrm{P} 14$ & $\begin{array}{l}\text { e. Memahami cara menganalisis hasil } \\
\text { pelaksanaan PTK }\end{array}$ \\
\hline & & $-\mathrm{P} 12$ & $\begin{array}{l}\text { f. Kesulitan melaporkan hasil PTK kedalam } \\
\text { penyusunan artikel }\end{array}$ \\
\hline \multirow[t]{6}{*}{4} & \multirow[t]{6}{*}{ Pengalaman } & $+\mathrm{P} 10$ & a. Sudah sering melaksanakan PTK di sekolah \\
\hline & & $+\mathrm{P} 8$ & b. PTK selama ini efektif dilakukan di sekolah \\
\hline & & $+\mathrm{P} 6$ & c. PTK dilaksanakan atas inisiatif sendiri \\
\hline & & $+\mathrm{P} 4$ & d. Sudah sering mengikuti seminar PTK \\
\hline & & -P2 & $\begin{array}{l}\text { e. Sarana dan prasarana sekolah kurang } \\
\text { mendukung pelaksanaan PTK }\end{array}$ \\
\hline & & -P21 & $\begin{array}{ll}\text { f. Kesulitan mengatur waktu untuk } \\
\text { melaksanakan PTK di sekolah }\end{array}$ \\
\hline
\end{tabular}

(Sumber: Diadaptasi dari Sukidjo, (2013))

Teknik analisis data angket menggunakan pemodelan Rasch untuk mengetahui gambaran respon peserta secara spesifik. Pemodelan Rasch merupakan bentuk analisis menggunakan teori modern yang menghubungkan antara responden dan item pertanyaan (Sumintono \& 
Widhiarso, 2013). Penggunaan pemodelan Rasch dalam analisis data sangat tepat, karena menggunakan prinsip pengukuran modern dengan mempertimbangkan berbagai aspek pengukuran.

\section{HASIL DAN PEMBAHASAN}

Pelatihan diawali dengan kegiatan pembukaan oleh Dekan FKIP UNIPA dilanjutkan dengan sambutan oleh ketua panitia dan pemaparan materi oleh tim PKM sebagai narasumber. Materi yang disampaikan dalam pelatihan ini yaitu tentang definisi dan hakikat PTK dibandingkan dengan penelitian lainnya, bidang garapan PTK, model-model PTK, mengidentifikasi permasalahan dalam PTK, judul PTK, teknik pengumpulan data PTK, analisis dan pelaporan hasil PTK. Pemaparan materi dilakukan melalui metode ceramah, diskusi, dan demonstrasi. Setelah pemaparan materi, selanjutnya peserta dilatih untuk menyusun perangkat PTK sebagaimana ditunjukkan pada Gambar 2. Sasaran utama kegiatan ini yaitu guru-guru diharapkan terampil dalam melakukan PTK. Pelaksanaan PTK perlu melibatkan berbagai pihak diantaranya yaitu pihak kampus atau dosen sebagai ahli dan pihak sekolah dalam hal ini guru sebagai praktisi. Kerjasama yang baik antara sekolah dengan pihak kampus dalam hal ini guru dengan dosen, dapat menjadi sarana yang efektif dalam mendiskusikan masalah belajar peserta didik untuk secara bersama dicarikan solusinya (Buaraphan, 2016). Penyelesaian masalah belajar peserta didik perlu dicarikan solusi yang tepat agar hasil belajar yang diharapkan dapat dicapai sesuai dengan tujuan pembelajaran. Gambar 2 memperlihatkan proses pelaksanaan pelatihan.



Gambar 2. Pelaksanaan Kegiatan Pelatihan PTK

Gambar 2 menunjukkan bahwa peserta pelatihan antusias dalam mengikuti pelatihan. Peserta yang mengikuti kegiatan pelatihan PTK sebagian besar belum pernah melaksanakan PTK di kelasnya. Berdasarkan audiensi dengan peserta, terdapat salah satu peserta yang pernah melakukan PTK namun masih kesulitan dan belum memahami dengan baik langkah-langkah dalam pelaksanaan PTK. Pelaksanaan PTK bagi guru sangat penting dilakukan agar guru dapat mengatasi berbagai 
permasalahan belajar yang dihadapi oleh peserta didik di kelas (Cain, 2011). Pelaksanaan PTK bagi guru berdampak pula terhadap peningkatan profesionalisme (Gibbs et al., 2017). Permasalahan belajar peserta didik perlu diatasi dengan menerapkan berbagai model pembelajaran inovatif yang dilakukan oleh guru.

Guru-guru yang mengikuti kegiatan pelatihan PTK yang diselenggaran oleh tim PKM FKIP UNIPA, masih kesulitan dalam menyusun perangkat PTK. Sebagian besar mengalami kesulitan dalam menyusun instrumen evaluasi PTK. Instrumen PTK disusun berdasarkan aspek apa saja yang akan dikembangkan dalam pembelajaran. Instrumen juga mencakup soal evaluasi yang diberikan selama pembelajaran. Apabila kualitas instrumen penelitian baik maka instrumen tersebut dapat mengukur dengan baik aspek atau kemampuan peserta didik dalam hal apa saja yang akan ditingkatkan (Istiyono, 2018). Melalui penggunaan instrumen yang baik dalam PTK, diharapkan dapat mengukur dengan tepat kemampuan yang akan dikembangkan selama proses pembelajaran.

Berbagai kegiatan inovatif yang diselenggarakan oleh pemerintah maupun lembaga swasta biasanya mensyaratkan guru untuk mampu menerapkan PTK di kelasnya. PTK penting dilakukan oleh guru karena guru mempunyai otoritas dalam menilai kinerjanya dan guru merupakan orang yang paling akrab dengan kondisi belajar peserta didik di kelasnya (Vogelzang \& Admiraal, 2017). Guru-guru yang terampil dalam melaksanakan PTK, mereka akan muda dalam mengatasi berbagai permasalahan belajar peserta didiknya. Ketika mereka mampu mengatasi masalah peserta didiknya, maka hasil belajar siswanya akan menjadi baik. Guru-guru akan terpacu menerapkan berbagai model pembelajaran inovatif serta menggunakan berbagai media pembelajaran dalam mengatasi permasalahan belajar peserta didik melalui PTK (Saleem, 2018). Melalui pelaksanaan PTK, guru-guru dapat memaksimalkan perannya sebagai pendidik yaitu memberikan pemahaman materi, melatihkan keterampilan, dan mengembangkan kepribadian yang baik bagi peserta didik.

Pada pelaksanaan pelatihan PTK, dilakukan kegiatan Small Group Discussion yaitu peserta dibagi kedalam kelompok untuk mendiskusikan secara lebih detail tentang permasalahan PTK sebagaiman ditunjukkan pada Gambar 3. Pada kegiatan ini juga didiskusikan kegiatan PTK yang akan diterapkan di sekolah. Guru-guru antusias mengutarakan ide dan gagasan, serta kesiapan mereka dalam menerapkan PTK di kelas masingmasing. Gambar 3 berikut memperlihatkan guru dalam mengutarakan ide mereka mengenai masalah yang dihadapi di kelas dan solusinya. 


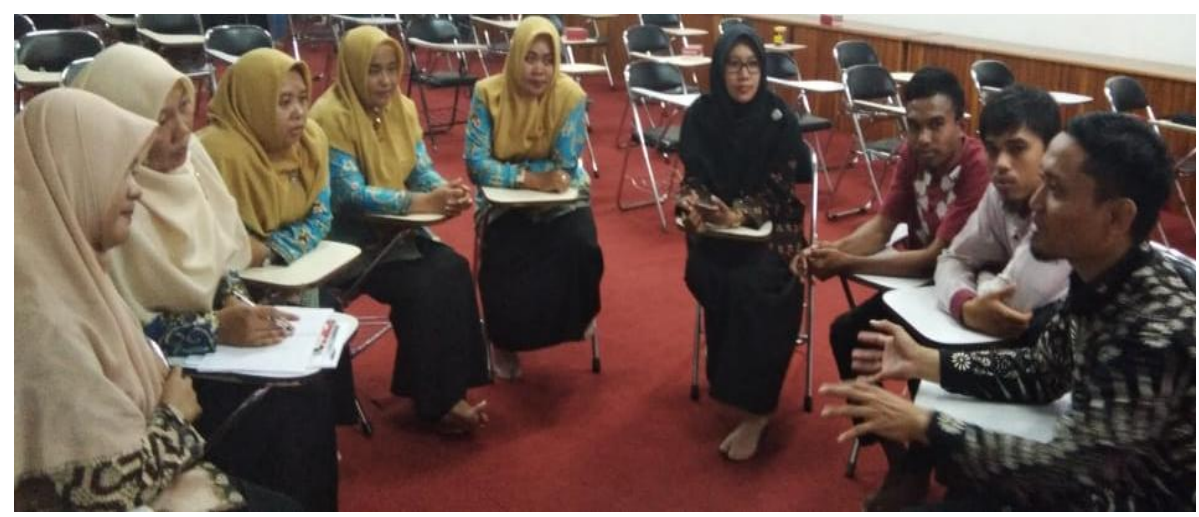

Gambar 3. Small Group Discussion Membahas Permasalahan dan Persiapan Pelaksanaan PTK

Gambar 3 menunjukkan pemateri dan peserta pelatihan saling berdiskusi dan memberikan ide tentang proses pelaksanaan PTK. Setelah kegiatan, mereka diberi angket untuk mengetahui respon mereka. Hasil analisis person reliability diperoleh 0,78 kategori cukup, yang menunjukkan bahwa konsistensi pilihan peserta pelatihan PTK cukup baik. Nilai item reliability diperoleh 0,91 kategori baik sekali, menunjukkan bahwa kualitas item yang digunakan dalam pelatihan baik sekali. Hasil analisis respon peserta pelatihan terhadap pelaksanaan PTK ditunjukkan pada Gambar 4.

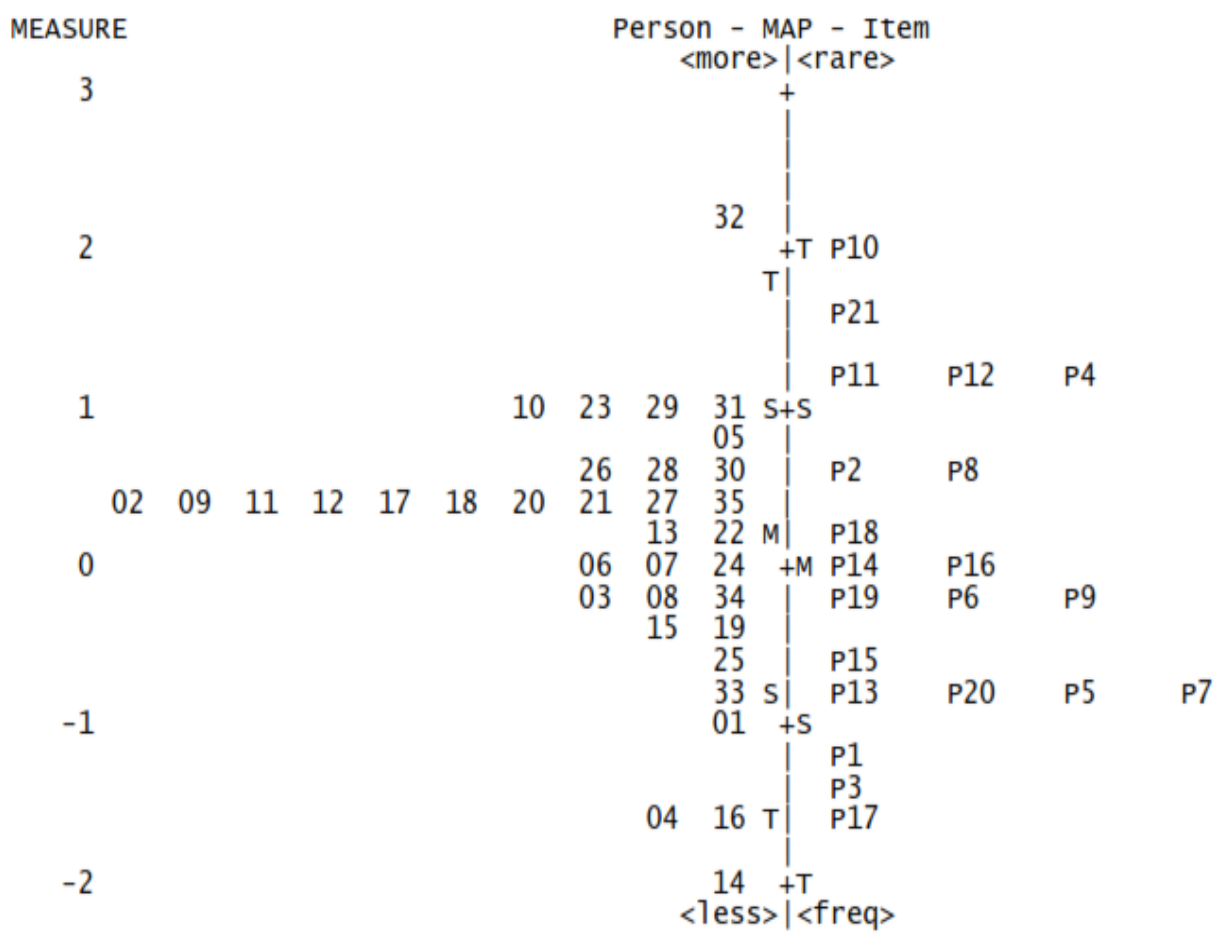

Gambar 4. Hasil Analisis Respon Guru terhadap Pelaksanaan Kegiatan Pelatihan

Gambar 4 menunjukkan hasil analisis respon guru terhadap kegiatan pelatihan. Hasil analisis dengan Rasch model diperoleh nilai person measure +0,11 lebih besar dari 0,00 logit yang menunjukkan bahwa peserta pelatihan setuju terhadap pembelajaran yang dilakukan. Pada bagian sebelah kiri gambar menunjukkan posisi person peserta dan pada sisi 
kanan menunjukkan posisi item pernyataan. Pada Gambar 4 terlihat bahwa $M$ logit item lebih kccil daripada M logit person. Hal ini menunjukkan bahwa tingkat persetujuan pernyataan lebih besar dibandingkan dengan kesulitasn mereka menyetujui penyataan. Peserta pelatihan mudah dalam menyetujui pernyataan yang disediakan pada angket. Guru-guru senantiasa merespon dengan baik kegiatan pelatihan yang dilakukan. Pelatihan PTK memberikan pemahaman yang baik bagi guru-guru dalam menyusun PTK (Buaraphan, 2016). Pemahaman PTK yang baik oleh guru, dapat menjadi sarana refleksi kegiatan pembelajaran untuk perbaikan secara terus menerus.

Pada bagian person terlihat bahwa terdapat 1 orang (32) yang menyetujui semua pernyataan yang diberikan. Hanya terdapat 1 orang (14) yang sangat sulit untuk menyetujui pernyataan pada angket. Pernyataan angket yang paling sulit disetujui yaitu P10 yang berkaitan dengan keseringan mereka melakukan PTK di sekolah. Pernyataan tersebut paling sulit disetujui karena sebagian besar guru-guru belum pernah melakukan PTK di kelas. Setelah pelaksanaan pelatihan PTK ini, mereka lebih termotivasi untuk menerapkan PTK dalam kelas. Pernyataan selanjutnya yang memiliki nilai logit yang tinggi atau sulit disetujui yaitu P21 tentang kesulitan bagi guru mengatur waktu untuk melaksanakan PTK di sekolah. Kondisi tersebut dialami oleh beberapa sekolah SMP di Kabupaten Manokwari Papua Barat, karena kurangnya tenaga guru khususnya IPA maka mereka lebih banyak jam mengajarnya. Hal ini merupakan salah satu alasan bagi guru untuk tidak dapat melakukan PTK di kelas. Persepsi guru terhadap PTK yaitu menganggap bahwa PTK dapat mengganggu kegiatan pembelajaran di kelas, padahal justru dengan PTK dapat merefleksi tugas guru sebagai orang yang lebih sering bertemu dengan peserta didik di kelas (Hong \& Lawrence, 2011). Pelaksanaan PTK di kelas merupakan salah satu langkah yang efektif untuk diterapkan dalam pembelajaran sehinggu guru-guru yang ada perlu dilatih dalam menyusun PTK.

\section{SIMPULAN DAN SARAN}

Simpulan yang diperoleh dari kegiatan pelatihan PTK ini yaitu peserta pelatihan dalam hal ini guru-guru IPA di Kabupaten Manokwari Papua Barat sebagian besar setuju dan memahami dengan baik tentang PTK. Guru-guru dapat menyusun perangkat PTK dan memahami dengan baik langkah-langkah dalam melaksanakan dan melaporkan hasil PTK. Hasil proses pelatihan menunjukkan bahwa guru-guru antusias dan mampu meningkatkan motivasi, kreativitas serta inovasi mereka dalam melakukan PTK. Para guru meminta adanya kerjasama yang terus terjalin antara pihak kampus dengan sekolah sebagai sarana yang efektif untuk perbaikan kualitas pembelajaran dan peningkatan profesionalisme guru dalam pembelajaran. 


\section{UCAPAN TERIMA KASIH}

Ucapan terimakasih kepada DRPM Ristek Dikti RI atas pendanan melalui hibah Program Kemitraan Masyarakat (PKM) tahun 2019 (Kontrak No. 081/SP2H/PM/DRPM/111/2019), LPPM Universitas Papua, Dinas Pendidikan Kabupaten Manokwari dan guru-guru SMP di Distrik Manokwari Barat dan Timur.

\section{DAFTAR RUJUKAN}

Amdriyani, S., Farida, Y. E., \& Wibowo, D. D. (2018). Pemberdayaan Guru Raudhatul Athfal (RA) Melalui Edukasi Media Visual "Buku Bantal Bilingual" di Sukosono Kedung Jepara Jawa Tengah. ENGAGEMENT; Jurnal Pengabdian Kepada Masyarakat, 2(1), 120-136.

Asmarani, N. (2014). Peningkatan Kompetensi Profesionalisme Guru di Sekolah Dasar. Jurnal Administrasi Pendidikan, 2(1), 503-510.

Buaraphan, K. (2016). The development of qualitative classroom action research workshop for in-service science teachers. Asia-Pacific Forum on Science Learning and Teaching, 17(1), 1-11.

Cain, T. (2011). Teachers' classroom- based action research. International Journal of Research \& Method in Education, 34(1), 3-16.

Ericson-Lidman, E., \& Strandberg, G. (2013). Care providers learning to deal with troubled conscience through participatory action research. Action Research, 11(4), 386-402.

Gibbs, P., Cartney, P., Wilkinson, K., Parkinson, J., Cunningham, S., James-Reynolds, C., Zoubir, T., Brown, V., Barter, P., Sumner, P., MacDonald, A., Dayananda, A., \& Pitt, A (2017). Literature review on the use of action research in higher education. Educational Action Research, 25(1), 3-22.

Hong, C. E., \& Lawrence, S. A. (2011). Action Research in Teacher Education: Classroom Inquiry, Reflection, and Data-Driven Decision Making. Journal of Inquiry \& Action in Education, 4(2), 1-17.

Istiyono, E. (2018). IT-based HOTS assessment on physics st learning as the 21 century demand at senior high schools: Expectation and reality IT-Based HOTS Assessment on Physics Learning as the 21 st Century Demand at Senior High Schools: Expectation and Reality. AIP Conference Proceedings, 2014(020014), 1-6.

Kemmis, S., McTaggart, R., \& Nixon, R. (2013). The action research planner: Doing critical participatory action research. Springer Science \& Business Media.

Kinsler, K. (2010). The utility of educational action research for emancipatory change. Action Research, 8(2), 171-189.

Saleem, M. (2018). Action Research as a Reflective Tool for Teachers in a Multicultural Education Class. Colleagues, 15(1), 1-10.

Siregar, E. (2014). Pengembangan Profesionalisme Guru Melalui Penelitian Tindakan Kelas. Jurnal Pengabdian Kepada Masyarakat, 20(77), 173-186.

Sukidjo. (2013). Kompetensi Penelitian Tindakan Kelas SMP DIY. Cakrawala Pendidikan, XXXIII(3), 368-378.

Sumintono, B., \& Widhiarso, B. (2013). Aplikasi Model Rasch untuk Penelitian Ilmu-ilmu Sosial. Cimahi: Trim Komunikata Publishing House.

Vogelzang, J., \& Admiraal, W. F. (2017). Classroom action research on formative assessment in a context-based chemistry course. Educational Action Research, $25(1), 155-166$.

Wiganda, S. (2017). Pelatihan Penelitian Tindakan Kelas Bagi Guru-Guru SeJakarta Timur. Sarwahita, 11(1), 7. https://doi.org/10.21009/sarwahita.111.01

Yamtinah, S., Saputro, S., \& Masykuri, M. (2011). Kinerja Guru IPA dalam Melaksanakan Proses Penelitian Tindakan Kelas. Jurnal Rehabilitasi Dan Remediasi (JRR), 20(1), 48-55. 